Aldo Barucq Muro Santoyo 


\section{Observaciones sobre la metáfora en el lenguaje}

\section{Introducción}

El lenguaje es esencialmente metafórico. Sin embargo, esto no conlleva a que todo el tiempo nos encontremos sumergidos en la retórica o la figuración para referir el mundo o para nuestros esquemas de comunicación, sino que más bien la proposición hace hincapié en la lógica metafórica sobre la que construimos nuestros esquemas conceptuales. Entendiendo la metáfora como traslatio, traslación, transposición y, por ende, movimiento, el presente trabajo analiza la presencia cognitiva, conceptual y sensorial de la metáfora en el lenguaje. Los esquemas lingüísticos del ser humano trabajan a partir de una lógica metafórica y estética en tanto sensible y mimética.

\section{Observaciones sobre la metáfora en el lenguaje}

Los tropos se caracterizan por ser figuraciones estéticas de la reali$\mathrm{dad}$, con esto, pasan por desviaciones del lenguaje $\mathrm{u}$ ornatos propios del lenguaje poético o de la creación artística. La tradición filosófica - cuya vena es dualista - ha exhibido que el lenguaje basado en la experiencia sensitiva no contribuye al conocimiento del mundo, no habla con verdad. Por el contrario, lo nubla y ofusca.

Platón, en el Cratilo se inclina por una teoría naturalista del lenguaje, es decir, que existe una relación natural entre concepto y objeto, y es en este mismo concepto natural donde recae la esencia de las cosas, y consiguientemente denuncia la ineficacia de los tropos en la construcción de la episteme. La metáfora, en tanto tropo, pertenece a la retórica, por lo que se entiende como sierva de la elocuencia y no de la verdad. La retórica, que Aristóteles define como 
"la facultad de observar todos los medios de persuasión sobre cada cosa”, e Isócrates como "conocimiento de persuasión" campo de la doxa según su carácter (poco confiable), por lo que su censura proviene directamente de la oposición entre opinión y conocimiento. En tanto que la episteme coincide con el conocimiento de las formas, la doxa refiere únicamente a los testimonios superficiales de las cosas captadas sensorialmente.

Cuando se le aplica una denominación metafórica a algo en particular, comúnmente lo que se habla se sitúa en un plano ficticio o poético, vecino a la fantasía, como una desviación en pocos casos lúdica. Las metáforas son falsas, mas no ilógicas, esto es, que su escaso valor para proporcionar información objetiva del mundo no reside en su forma sino en su contenido. Si bien es cierto que existe una demarcación lingüística de los objetos más allá del uso o conjugación retórica que se les pueda dar, con la conformación del lenguaje viene también la asimilación de sus características; como que algunos tienen la capacidad de dar cabida a otros objetos, tienen una rugosidad, color o forma similares a las de otros al grado de permitirnos encontrar "perlas en el rocío" o "lunas de queso".

El ser humano nota, a través de sus propios esquemas conceptuales, que los objetos pueden conectarse entre sí, por trayectorias que pueden ser directas, cortas, largas, indirectas, horizontales, verticales, etcétera. Tales relaciones entre los objetos son lo que permite la referenciación del mundo, en tanto estados de cosas interactuando entre sí, como menciona Schopenhauer, o hechos cuya referenciación lingüística les es natural, según Wittgenstein.

La metáfora tiene su lugar entre los tropos o figuras de palabra, donde esta misma abarca, en términos generales, la esencia de este grupo lingüístico. La mayoría de los tropos operan como formas de metáforas. La Real Academia Española (RAE) define el tropo como el "empleo de una palabra en sentido distinto del que propiamente le corresponde, pero que tiene con éste alguna conexión, correspondencia o semejanza" ${ }^{\prime 2}$. Mientras que metáfora se define como "traslación del sentido recto de una voz a otro

1 Isócrates en Friedrich Nietzsche, "Descripción de la retórica antigua" en Escritos sobre retórica, trad. Luis Enrique de Santiago Guervós, Ed. Trotta, España, 2000, p. 83.

2 RAE, “Tropo", http://dle.rae.es/srv/fetch?id=aoA65RN (consultado el 02 de febrero de 2017). 


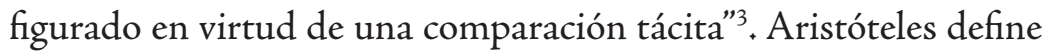
la metáfora como "la traslación de un nombre ajeno, o desde el género a la especie, o desde la especie al género, o desde una especie a otra especie, o según la analogía" ${ }^{4}$. Se reitera la semejanza entre tropo y metáfora. A pesar de que esta investigación no se centra en el estudio o análisis semántico o pragmático de la metáfora como tropo, sí se profundiza primeramente en su estudio morfológico, para luego trasladar su estructura trópica hacia la lógica del lenguaje, una vez que se entienda también a este tropo como traslatio o transposición.

Considero necesario enfatizar que la metáfora se entiende esencialmente en términos de movimiento, por ello la denominación de traslatio. Propongo entender la metáfora como un movimiento cognitivo y conceptual dentro de los esquemas lingüísticos. Y además comprender la dirección del movimiento en la metáfora en dos sentidos: "horizontal cuando se habla a nivel conceptual y "vertical", a nivel cognitivo. Se entiende por movimiento horizontal de la metáfora cuando ésta se traslada entre cosas, objetos o referencias pertenecientes a un mismo nivel cognitivo, que es como usualmente se nos presenta una metáfora que asocia dos términos concretos ya conocidos. En tanto que la metáfora de movimiento vertical se entenderá por el salto o transposición (übertragung) que ocurre entre ámbitos, materiales o niveles cognitivos diferentes, sea por naturaleza.

Metáfora como traslación vertical. Entre los filósofos que han abogado por un funcionamiento sensitivo (¿artístico?) del lenguaje a través de la metáfora se encuentran Gotffried Herder en su "Ensayo sobre el origen del lenguaje", Giambattista Vico en la Scienza Nuova, Gustav Gerber en Die Sprache als Kunst y Nietzsche en "Sobre verdad y mentira en sentido extramoral" y en la compilación de los tempranos Escritos sobre retórica, reunidos por Luis Enrique de Santiago Guervós, principalmente. Tales estudios abordados principalmente en el romanticismo sitúan a la metáfora como un elemento operacional de suma importancia en el lenguaje.

Para Herder, la sensibilidad es común a la naturaleza animal, presente también en el hombre, pero que gracias a la reflexión

3 RAE, "Metáfora", http://dle.rae.es/srv/search?m=30\&w=met\%C3\%A1fora(consultado el 02 de febrero de 2017).

4 Aristóteles, Poética, trad. Valentín García Yebra, Gredos, España, 2010, p. 428,10 . 
humana puede refinarse y referir la multiplicidad del mundo acorde a la variedad de imágenes que la razón permite crear y entender. El ser humano conforma estructuras lingüísticas más complejas y amplias que otro animal, en la medida en que es capaz de significarse el mundo proposicionalmente $y$, además, de reinventar y redescribir sus esquemas lingüísticos con base en sus deseos, creatividad y valoraciones. De acuerdo con lo anterior, el lenguaje es primeramente un impulso sensitivo que más tarde tiene la necesidad de comunicarse, reproducirse en términos o condiciones diferentes a los que originalmente se ha adquirido -ise transpone la percepción sensitiva a otros ámbitos diferentes como representaciones abstractas, imágenes y sonidos!

Retomando las definiciones de "metáfora" antes expuestas donde se define la "traslación del sentido recto de una voz a otro figurado en virtud de una comparación tácita" o como "la aplicación a una cosa de un nombre que es propio de otra" $\mathrm{e}$ identificándola primero en términos de movimiento vertical, decimos que se presenta como una transposición de elementos pertenecientes a niveles naturales distintos, pues "¿Qué es una palabra? La reproducción en sonidos de un impulso nervioso"7. Aquí se expresa una cosa en términos de otra que no pertenecen al mismo nivel. Un sonido y un impulso nervioso no comparten el mismo peldaño cognitivo. Esto sería una descripción simplificada del proceso para erigir el velo lingüístico que intenta "expresar adecuadamente todas las realidades", pues para Nietzsche el proceso es:

¡En primer lugar, un impulso nervioso extrapolado en una imagen! Primera metáfora. ${ }_{i}$ La imagen transformada de nuevo en un sonido! Segunda metáfora. Y en cada caso, un salto total desde una esfera a otra completamente distinta. [...] Del mismo modo que el sonido configurado en la arena, la enigmática $\mathrm{x}$ de la cosa en sí, se presenta en principio como impulso nervioso, después como figura, finalmente como sonido. ${ }^{8}$

5 RAE, "Metáfora", http://dle.rae.es/srv/search?m=30\&w=met\%C3\%A1fora (consultado el 02 de febrero de 2017).

6 Aristóteles, op. cit., p. 428, 10.

7 Nietzsche, op. cit., p. 25.

8 Ibidem pp. 26-27. 
En "Metáfora y conocimiento. Estudio de la crítica al conocimiento llevada a cabo por Nietzsche en Sobre verdad y mentira en sentido extramoral y en la Genealogía de la moral", Indalecio García esquematiza la misma fórmula de Nietzsche citada anteriormente:

1. Se ha tomado un impulso nervioso y se lo ha vinculado a una imagen,

2. Se ha tomado esa imagen y se la ha vinculado a un sonido (palabra),

3. A partir de estos sonidos se habrían originado los conceptos. ${ }^{9}$

La condición metafórica del lenguaje reside en la traslación de un ámbito a otro sin relación natural o intrínseca entre sí. El impulso nervioso, la imagen, el chillido, el concepto, son de distinta naturaleza. El movimiento metafórico aquí se presenta de forma vertical, entre niveles distintos. De ahí que Nietzsche hable de un "salto total de una esfera a otra". Hay una conexión arbitraria de estas esferas inmiscuidas en la interacción sujeto-objeto, en la opinión que el ser humano tiene del mundo y que a través de su lenguaje le posibilita postular formas en la naturaleza. Cabe destacar que la fórmula que utiliza Nietzsche para explicar la esencia metafórica del lenguaje tiene influencia de la obra de Gustav Gerber ${ }^{10}$

Metáfora como movimiento horizontal. Aparece nuevamente en escena la definición aristotélica de metáfora que "consiste en trasladar a una cosa un nombre que designa otra, una traslación de género a especie o de especie a género o de especie a especie, o según una analogía" ${ }^{\prime 1}$. El movimiento metafórico se presenta aquí de forma horizontal, a nivel conceptual, entre componentes ya delimitados.

Así pues, la traslación horizontal es evidente en metáforas tal y como las conocemos usualmente, en expresiones como "las

9 Indalecio García, "Metáfora y conocimiento. Estudio de la crítica al conocimiento llevada a cabo por Nietzsche en Sobre verdad y mentira en sentido extramoral y en la Genealogía de la moral', Euphyía No. 15, 2014, pp. 91-105.

10 Gerber describe la configuración de los esquemas lingüísticos de la siguiente manera: Cosa en sí-impulso nervioso-sensación-sonido (imagen externa)representación (imagen interna)-raíz-palabra-concepto.

11 Aristóteles, op. cit., p. 1457, b. 
perlas del rocío", “Laura es la luna”,"la argumentación es una guerra", y en otras expresiones que referimos de manera cotidiana con un núcleo claramente metafórico y comparativo, como cuando se atribuye valor monetario al tiempo, orientaciones espaciales a los estados de ánimo o entender a las palabras como recipientes de ideas.

El hombre configura su lenguaje, por medios sensibles y por las cualidades de los objetos, e identifica, a su vez, la forma en la que éstos se interconectan para dar lugar a hechos. Tal proceso no es posible sin un núcleo corpóreo. El ser humano descubre qué objetos que se parecen, cuáles actúan de manera similar, en qué circunstancias mantienen cualidades o comportamientos afines y si sus imágenes pueden expresarse en términos similares. De ahí que Aristóteles señale que "hacer buenas metáforas es percibir la semejanza." ${ }^{12} \mathrm{Tal}$ reconocimiento es primeramente sensible, luego conceptual, esto es, cuando las representaciones subjetivas y particulares de un mismo objeto u objetos pertenecientes a la misma especie se unifican y objetivan en una imagen, concepto general o en un grupo o parecido de familia donde éstos puedan converger por su similud:

Los objetos pueden formar una clase a cuyos miembros el predicado $\mathrm{P}$ puede ser correctamente adscrito sin asumir que existe un universal el cual es actualizado por cada objeto. Se asume, por el contrario, que en una clase de "aires de familia", los miembros de todos los pares de objetos en la clase evocan uno a otro ciertos aspectos relevantes a $\mathrm{P}$, y que esas evocaciones forman un tipo de estructura encadenada de semejanzas a lo largo de la clase, de tal forma que existen casos relativamente claros de objetos que quedan dentro de la clase y casos relativamente claros de objetos que no. ${ }^{13}$

Se explican los conceptos y sus significados como clasificaciones normativas de grupos o clases de experiencias que comparten relaciones más o menos estables de semejanza y equivalencia entre los elementos que conforman la extensión de cada predicado

12 Aristóteles, op. cit., p. 432, 5 .

13 Hesse, Mary en Rubén Sampieri, Ciencia y metáfora. Una perspectiva desde la filosofía analítica, UNAM, México, 2014, p. 62. 
de esas clasificaciones y no como correlatos de una correspondencia lenguaje-mundo o de un descubrimiento de esencias universales absolutas.

El siguiente esquema representa visualmente ambos movimientos metafóricos y el sentido en que operan en el funcionamiento del lenguaje:

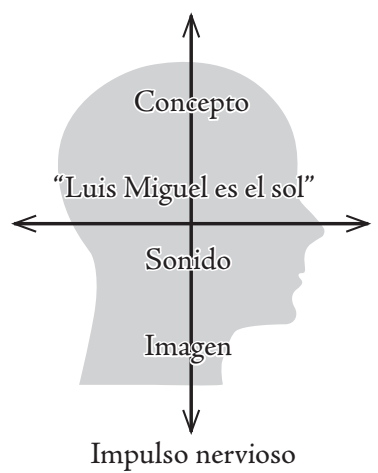

El lenguaje tiene un núcleo corpóreo o material no sólo por el reconocimiento de semejanzas y diferencias en los objetos a través de la interacción con ellos, sino también para facilitar la comprensión de conceptos o ideas abstractos. Los pensamientos o ideas son objetos físicos: se pueden esconder, ocultar, velar, descubrir, mostrar, etcétera: Luis me dio una idea, Métete esa idea en la cabeza, Él me quitó la idea. Las palabras son objetos físicos: No le pude sacar ni una palabra, Me arrebataron la palabra de la boca, Su nombre está en boca de todos. Y por último, las palabras son contenedores de ideas: No lo puedo decir en menos palabras, Tus palabras están vacías, No encontré contenido en sus palabras.

Por último, se examinará la presencia de la mímesis en la conceptualización y configuración con que construimos acciones y comportamientos de manera cotidiana y que tienen como origen la traslación de una imagen metafórica. Para tener una idea completa de lo que se entiende por mímesis en este apartado y cómo se suma ésta a la configuración figurativa del lenguaje, se tomarán en cuenta las siguientes definiciones. Para Helena Beristáin, en su Diccionario de retórica y poética,"la mímesis consiste en la imitación de la realidad 
de la vida"14. Agrega, recurriendo a Lausberg, que la mímesis es "un instrumento cognoscitivo ontológico/sociológico, de trabajo y divulgación, sin el cual la vida espiritual no sería posible." ${ }^{15}$

A través de la mímesis, se transporta la copia conceptual de algún término específico a acciones determinadas, que en cierto sentido se parecen; nuevamente se busca "igualar lo semejante", lo que bajo ciertas circunstancias encontramos similar, sea por analogía o por cualidades compartidas. Lo importante es resaltar la capacidad para configurar acciones cotidianas y entender su estructura con base en imágenes mentales.

Así pues, podemos encontrar acciones cotidianas que tienen como principal referente una imitación de la imagen mental a la que asociamos tales actos. La mímesis muestra el campo práctico de la metáfora cuando realizamos acciones a través de metáforas tales como concebir la argumentación como una guerra, concebir y realizar el discurso como un hilar, concebir estados de ánimo como orientaciones espaciales y levantar el pulgar hacia arriba para dar a entender que te gusta la foto de tu amiga o direccionarlo hacia abajo para expresar, en el coliseo romano, que los gladiadores debían morir, entre otras acciones.

Cognitivamente la metáfora funge como reguladora del lenguaje, pues hace posible el concebir algo o pensar por medio de un proceso de manipulación de imágenes mentales, pues se busca que los objetos físicos se unifiquen en la imagen, que más tarde habrá de buscar relaciones miméticas respecto de objetos semejantes, para atribuir nuevas designaciones o formas discursivas.

\section{Conclusión}

Se ha expuesto un breve esbozo de cómo es que se estructura el lenguaje desde un origen sensible hacia una lógica metafórica de su funcionamiento. Situando primero a la metáfora como transposición o traslación se reivindica su carácter cinético en nuestros esquemas conceptuales y cognitivos. Suponer que el lenguaje surge y opera a través de una vena sensible es dotarlo de un carácter

14 Beristáin, Helena, Diccionario de retórica y poética, Porrúa, México, 1985, p. 333.

15 Idem. 
doxástico, lejano a la referencia natural o la expresión de la verdad en el mundo, para reducirlo a una herramienta, aunque útil, que sólo refiere la manera casi artística en la que el hombre se relaciona con las cosas y emite una opinión de éstas.

El hombre que configura el lenguaje no percibe cosas o eventos, sino impulsos (Reize): él no transmite sensaciones, sino sólo copias de sensaciones. La sensación suscitada a través de una excitación nerviosa, no capta la cosa misma: esta sensación es representada externamente a través de una imagen. Pero hay que preguntarse, sin embargo, cómo un acto del alma puede ser representado a través de una imagen sonora (Tonbild) [...] No son las cosas las que penetran en la conciencia, sino la manera en que nosotros estamos ante ellas ${ }^{16}$.

Con base en lo que se ha dicho hasta ahora, podemos concluir que el lenguaje tiene muy poca relación con la verdad, con la esencia de las cosas. Que el lenguaje no tiene la finalidad inherente o la estructura para comunicar lo verdadero, sino que se enfoca en transmitir emociones, impulsos, aprehensiones, de una manera estilizada y uniforme, las formas en la naturaleza son un efecto secundario del carácter ontológico del lenguaje. Pero entonces, ¿¿qué pasa con el sentido literal de las palabras?, ¿qué con el conocimiento?, ¿qué con la filosofía?, ¿qué con todos estos lenguajes fantásticos y figurativos?

16 Nietzsche, op. cit., "Curso sobre retórica”, p. 91. 